\title{
Physiological studies of Colletotrichum musae the causal agent of Anthracnose disease of banana
}

\author{
Rani R. Unnithan, N. Thammaiah*, M. S. Kulkarni and P. M. Gangadharappa
}

Department of Plant Pathology, College of Horticulture, Yelachanahalli Horticulture Farm, Yelwal Hobli, Mysuru (Karnataka) India

\section{ARITCLE INFO \\ Received : 01.11 .2017 \\ Revised : 15.03 .2018 \\ Accepted : 23.03.2018}

\section{KEY WORDS :}

Banana, Colletotrichum musae, Temperature, Light, $\mathrm{pH}$

*Corresponding author: nthammaiah@gmail.com

\begin{abstract}
Effect of different temperature, light intensity and $\mathrm{pH}$ were tested against the growth and sporulation of Colletotrichum musae under in vitro conditions. Results indicated that the growth of Colletotrichum musae was maximum at $30^{\circ} \mathrm{C}(72.25 \mathrm{~mm})$ followed by $25^{\circ} \mathrm{C}(68.25 \mathrm{~mm}), 20^{\circ} \mathrm{C}(53.00 \mathrm{~mm}), 15^{\circ} \mathrm{C}(52.75 \mathrm{~mm})$ and it was lowest growth $(12.00$ $\mathrm{mm})$ at $35^{\circ} \mathrm{C}$. Exposure of Colletotrichum musae to alternate cycles of $12 \mathrm{hr}$ light and $12 \mathrm{hr}$ darkness, continous light and under normal condition (room temperature) resulted in the maximum mycelial growth $(90.00 \mathrm{~mm})$ and heavy sporulation. The variation in growth of Colletotrichum musae at different $\mathrm{pH}$ were found to be significant. Result of the study revealed that at $\mathrm{pH} 7.0$ fungus produced maximum growth of $977.0 \mathrm{mg}$ followed by $960.0 \mathrm{mg}$ at $\mathrm{pH} 8.0,957.0 \mathrm{mg}$ at $\mathrm{pH} 6.0,948.0 \mathrm{mg}$ at $\mathrm{pH} 5.0$ and $922.0 \mathrm{mg}$ at $\mathrm{pH} 4.0$.
\end{abstract}

How to view point the article : Unnithan, Rani R., Thammaiah, N., Kulkarni, M.S. and Gangadharappa, P.M. (2018). Physiological studies of Colletotrichum musae the causal agent of Anthracnose disease of banana. Internat. J. Plant Protec., 11(1) : 87-92, DOI : 10.15740/HAS/ IJPP/11.1/87-92. 